\title{
Aikuiskasvatuksen tehtäväalueet
}

Alanen, Aulis. 1981. Aikuiskasvatuksen tehtäväalueet. Aikuiskasvatus 1, 1, 15-19. Tehtäväluokitusten kansainvälinen vertailu osoittaa, että eri maissa on päädytty pitkälle yhdenmukaiseen keskeisten tehtäväkategorioiden erotteluun. Suomessa kritiikkiä aiheuttanut aikuiskoulutuskomitean nelijako ei siten ole olennaisesti uusi eikä poikkeuksellinen. Kirjoittaja kysyy, mitkä ovat luokitusten jäsentelyperusteet ja päätyy käsitykseen, että tehtävien jäsentyminen lähtee aikuisen elämänalueista, joiden mukaan opintotavoitteet eriytyvät. Kirjoitus on tarkoitettu pohjustukseksi harrastusopintojen käsitteen pohdinnalle, johon tekijän on tarkoitus palata eri artikkelissa.

Aikuiskasvatuksen käsitteistä ja termeistä käyty keskustelu on viime aikoina suuntautunut muun muassa tehtäväalueiden jäsentämiseen. Aikuiskoulutuskomitean esittämään tehtävien nelijakoon on kohdistettu osin hyvin jyrkkääkin kritiikkiä. Arvostelun yhtenä ärsykelähteenä on ollut se, että tehtäväalueet ovat valtion kehittämissuunnitelmissa joutuneet tiettyyn prioriteettiasetelmaan, jonka monet ovat päinvastaisista vakuutuksista huolimatta tulkinneet arvojärjestykseksi. Erityisesti harrastustavoitteisen koulutuksen on katsottu tulleen syrjityksi. Samalla on jouduttu pohtimaan käsitteen merkityssisältöä — tehtäväalue on harmillisen usein samastettu harrasteisiin sanan suppeassa merkityksessä - ja sitä edustavan termin osuvuutta.

Tämäkin kirjoitus lähti liikkeelle halusta selvitellä harrastusopintojen olemusta. Pidän kuitenkin tarpeellisena ensin tarkastella tehtäväalueiden jäsentymistä kokonaisuutena, joten keskityn tällä kertaa siihen ja palaan harrastusopintojen käsitteen ja aseman pohdiskeluun toisella kertaa.

\section{Luokitusten kansain- välistä vertailua}

Aikuiskoulutuskomitean II mietinnössään (mt. s. 29-32) esittämä tehtäväalueiden nelijako - yleissivistävän pohjakoulutuksen täydentäminen, ammatillinen aikuiskoulutus, yhteiskunnallinen koulutus ja harrastustavoitteinen koulutus - ei luokituksena ollut mitenkään uusi eikä omaperäinen; tehtävien tämänmukainen eriytyminen käytännön toiminnassa oli varsin selvä. Esimerkiksi vuonna 1967 pidetyssä IX kansansivistyskokouksessa, siis vapaan sivistystyön piirissä, oli esitetty jotakuinkin samat neljä tehtäväluokkaa käsittävä jäsentely: "Aikuiskasvatukseen voidaan laskea kuuluviksi erilaisiin todistuksiin ja tutkintoihin tähtäävät opinnot, ammattipätevyyden hankkimiseksi suoritettavat opinnot sekä orientoivat opinnot... Näistä mainittakoon yhteiskunnallisesti orientoivat oppiainekset... sekä kultturellisesti orientoivat oppiainekset", (Vapaa kansansivistystyö... 1967, 79-80). Kansainvälinen vertailu osoittaa, että eri maissa on yhteiskuntajärjestelmästä riippumatta päädytty hyvin samantapaisiin tehtäväluokkiin. Kiinnostavia eroavuuksiakin on mutta yritän tässä yhteydessä lähinnä eritellä yhtäläisen jäsentymisen perusteita.

Olen luokitusten vertailemista varten poiminut eri maiden kirjallisuudesta sattumanvaraisesti noin kolmenkymmenen esimerkin aineiston (dokumentoin niistä tässä vain osan ettei 
viitteistö paisu kovin raskaaksi). Eniten luokituksia tapaa mietinnöistä ja muista suunnitteluasiakirjoista sekä maan aikuiskasvatustoimintaa kokonaisuutena esittelevistä deskriptiivistä katsauksista. Jäsentelyjen teoreettiset perustelut ovat tämän vuoksi jääneet yleensä vähälle.

Ammatillinen aikuiskoulutus erotetaan omaksi tehtäväalueekseen aineistoni jokseenkin kaikissa luokituksissa - tämä osoittaa samalla, että laajentunut, kaikki aikuisopintojen muodot kattava aikuiskasvatuksen määritelmä on jo yleismaailmallisesti varsin vakiintunut. Lähes yhtä yleisesti esiintyy tehtäväalueena "toinen koulunkäynnin mahdollisuus" ("second chance"') eli koulukursseja vastaavat aikuisopinnot. Nämä kaksi ovatkin toimintamuotoina eriytyneet selvimmin omiksi kokonaisuuksikseen. Niiden tavoitteet ja sisällöt ovat suhteellisen kiinteästi määräytyneitä ja järjestäjinä toimivat organisaatiotkin ovat usein erikoistuneet pelkästään koulu- tai ammattiopintoihin (meillä iltaoppikoulut ja ammatilliset aikuisoppilaitokset).
Ne aikuisopinnot, jotka eivät sijoitu kumpaankaan mainittuun kategoriaan, käsittävät itse asiassa valtaosan perinteisen aikuiskasvatuksen, pohjoismaisittain vapaan sivistystyön, tehtäväkentästä. Tämä moniaineksinen opintojen joukko on jaoteltu usealla eri tavalla. Olen taulukkoon 1 koonnut esimerkkejä sellaisista luokituksista, joissa kaksi ensiksi mainittua tehtäväaluetta on esitetty suunnilleen yhdenmukaisesti mutta joissa niiden lisäksi on toisistaan poikkeavasti yksi, kaksi tai kolme tehtäväluokkaa. Sisältyykö näihin luokituseroihin erilaisia näkemyksiä yhteiskunnan aikuiskasvatustehtävien jäsentymisestä? Käsitteiden muodostuksessa on eroavuuksia, joilla teoreettisen kiinnostavuuden lisäksi on suoraa aikuiskoulutuspoliittista merkitystä. Päähuomio tässä yhteydessä on kuitenkin, että kaikki luokitukset sisältävät olennaisesti samat tavoite- ja sisältökokonaisuudet, eri tavoin luokiksi yhdistäen mutta pitkälle samalla tavoin niiden sisällön jäsentäen.

Taulukko 1. Aikuiskasvatuksen tehtäväalueiden luokittamistapoja: kansainvälistä vertailua.

\begin{tabular}{|c|c|c|c|c|c|}
\hline $\begin{array}{l}\text { Ruotsi: } \\
\text { Eliasson } \\
\text { \& Höglund }\end{array}$ & $\begin{array}{l}\text { Neuvosto- } \\
\text { liitto } \\
\text { Kuljutkin }\end{array}$ & $\begin{array}{l}\text { Irlanti: } \\
\text { Kom.miet. }\end{array}$ & $\begin{array}{l}\text { Suomi: } \\
\text { Kom.miet. }\end{array}$ & $\begin{array}{l}\text { Saksan liitto- } \\
\text { tasavalta } \\
\text { Kom.miet. }\end{array}$ & $\begin{array}{l}\text { USA: } \\
\text { Liveright } \\
\text { \& Haygood }\end{array}$ \\
\hline $\begin{array}{l}\text { Todistus- } \\
\text { opinnot }\end{array}$ & $\begin{array}{l}\text { Kouluopiskelu- } \\
\text { järjestelmä }\end{array}$ & $\begin{array}{l}\text { Pohjakoulutus- } \\
\text { tehtävä }\end{array}$ & $\begin{array}{l}\text { Pohjakoulutuk- } \\
\text { sen täydentämi- } \\
\text { nen }\end{array}$ & $\begin{array}{l}\text { Koulututkinto- } \\
\text { ja vastaavat } \\
\text { opinnot }\end{array}$ & $\begin{array}{l}\text { Koulunkäyntiä } \\
\text { korvaavat } \\
\text { opinnot }\end{array}$ \\
\hline $\begin{array}{l}\text { Ammattiin liit- } \\
\text { tyvät opinnot }\end{array}$ & $\begin{array}{l}\text { Ammattitaidon } \\
\text { kehittäminen ja } \\
\text { uudelleenkoulutus }\end{array}$ & $\begin{array}{l}\text { Ammatillinen } \\
\mathrm{j}\{\text { : taloudellinen } \\
\text { tehtävä }\end{array}$ & $\begin{array}{l}\text { Ammatillinen } \\
\text { aikuiskoulutus }\end{array}$ & $\begin{array}{l}\text { Ammatillinen } \\
\text { aikuiskoulutus }\end{array}$ & $\begin{array}{l}\text { Ammatillisesti } \\
\text { pätevöivä } \\
\text { koulutus }\end{array}$ \\
\hline \multirow[t]{2}{*}{$\begin{array}{l}\text { Vapaa-aikaan } \\
\text { suuntautuvat } \\
\text { opinnot }\end{array}$} & \multirow[t]{2}{*}{$\begin{array}{l}\text { Koulun ulkopuo- } \\
\text { linen yleis- } \\
\text { sivistävä koulutus }\end{array}$} & $\begin{array}{l}\text { Poliittinen } \\
\text { tehtävä }\end{array}$ & $\begin{array}{l}\text { Yhteiskunnalli- } \\
\text { nen koulutus }\end{array}$ & $\begin{array}{l}\text { Poliittinen } \\
\text { kasvatus }\end{array}$ & $\begin{array}{l}\text { Poliittinen, } \\
\text { kansalais- ja } \\
\text { yhdyskunta- } \\
\text { kasvatus }\end{array}$ \\
\hline & & $\begin{array}{l}\text { Persoonallisuu- } \\
\text { den kehittämis- } \\
\text { tehtävä }\end{array}$ & $\begin{array}{l}\text { Harrastus- } \\
\text { tavoitteinen } \\
\text { koulutus }\end{array}$ & $\begin{array}{l}\text { Pohjasivistyk- } \\
\text { sen laajenta- } \\
\text { minen } \\
\text { Muu aikuis- } \\
\text { kasvatus }\end{array}$ & $\begin{array}{l}\text { Terveyteen, hy- } \\
\text { vinvointiin ja } \\
\text { perhe-elämään } \\
\text { suuntautuva kas- } \\
\text { vatus } \\
\text { Itseä toteutta- } \\
\text { vat opinnot }\end{array}$ \\
\hline
\end{tabular}

Lähteet: Eliasson \& Höglund 1971: 1:25-27; Kuljutkin 1974, 14; Adult Education in Ireland 1973, 11-14; Kom. miet. 1975:28, 29-32; Strukturplan für das Bildungswesen 1970, 53-57; Liveright \& Haygood 1969,7.

Otan yksityiskohtaisemman vertailun lähtökohdaksi Liverightin ja Haygoodin luokituksen, koska se on pisimmälle eriytetty. Tämä luokitus on muuten kansainvälisesti tunnetuin $\mathrm{mm}$. sen vuoksi, että Unesco on käyttänyt sitä Tokion maailmankonferenssille valmistamassaa raportissa (Unesco 1972, 24-27), samoin Lowe Unescon julkaisemassa "maailmanperspektiiviin"' pyrkivässä yleisteoksessaan (Lowe $1975,55)$. Myös OECD on ottanut sen aikuiskoulutuspolitiikkaa käsittelevään raporttiinsa melkein sellaisenaan (OECD 1976, 8-9). Suo- men komitean sihteerinä voin todeta, että samaa mallia on käytetty hyväksi meidän nelijakomme muotoilussa; itse jaottelu kylläkin on vanhempi kuten alussa kävi ilmi.

Yksi Liverightin ja Haygoodin tehtäväluokista on kasvatus jonka tavoitteena on aikuisen poliittinen, yhdyskunnallinen ja muissa kansalaistoiminnoissa tavitsema pätevyys (Education for civic, political and community competence). Vertailu osoittaa, että vastaava tehtäväalue - yhteiskunnallinen/poliittinen kasvatus - on omana luokkanaan myös taulukon 
muissa vähintään nelijakoisissa luokituksissa. Kuljutkin puolestaa sisällyttää yhteiskunnallis-poliittiset tehtävät koulun ulkopuolisiin yleissivistäviin opintoihin. Eliasson ja Höglund, jotka erottelevat opintotavoitteita sosiaalisten roolien mukaan, mainitsevat vapaa-ajan rooleina "poliittisen kansalaisen", ja järjestöjen jäsenen. Koko aineistossa yhteiskunnallinen kasvatus on koulu- ja ammattiopintojen jälkeen tavallisimmin omaksi tehtäväalueekseen erotettu luokka.

Liverightin ja Haygoodin luokituksen erityispiirteeksi osoittautuu terveyteen, hyvinvointiin ja perhe-elämään suuntautuvan kasvatuksen (Education for health, welfare and family living) erottaminen omaksi tehtäväalueekseen. Taulukon muissa luokituksissa vastaavaa kategoriaa ei ole ja koko aineistossakin se on harvinainen (Parkynin tehtäväluettelossa on koulu- ja ammattiopintojen lisäksi kotikeskeiset, kansalais- ja kulttuuriopinnot; Parkyn 1973, 22-23). Osittain tämä selittyy sillä, että Yhdysvaltain aikuiskasvatuksessa vanhempainkasvatus, terveyskasvatus ja erinimikkeiset sosiaalisen kasvatuksen muodot ovat olleet eriytyneemmin esillä kuin Euroopassa. Taulukon toiset luokitukset sisällyttävät kuitenkin vastaavia tehtäviä muihin kategorioihin. Aikuiskoulutuskomitean nelijaossa ne jakautuvat yhteiskunnallisen ja harrastustavoitteisen koulutuksen kesken. Irlannin komitea taas, joka katsoo persoonallisuuden kehittämisen suuntautuvan lähinnä vapaa-aikaan, erittelee oppimistehtäviä asettavina vapaa-ajan toimintoina mm. psyykkisen ja fyysisen kunnon hoitamisen, perhe-elämän integroimisen, lasten kasvatuksen ja hoidon sekä osallistumisen sosiaaliseen elämään.

Itseä toteuttavat opinnot (Education for self-fulfilment) sisältävät Liverightin ja Haygoodin mukaan erilaiset yleissivistävät opinnot (liberal education), musiikin ja muiden taiteenalojen sekä kätten taitojen opinnot; yleensä opinnot joiden tarkoituksena on ensisijaisesti oppiminen oppimisen vuoksi. Aikuiskoulutuskomitean harrastustavoitteiset opinnot ja Irlannin komitean persoonallisuuden kehittäminen ovat olennaisesti samansisältöisiä sillä erotuksella, että ne sisältävät aineksia myös Liverightin ja Haygoodin edellisestä luokasta. Saksan liittotasavallan komitea näyttää hiukan muista poikkeavassa luokituksessaan tarkoittavan pohjasivistyksen laajentamisella ja "'muulla aikuiskasvatuksella"' suunnilleen samaa aluetta kuin aikuiskoulutuskomitea harrastustavoitteisella koulutuksella. 'Muun aikuiskasvatuksen" ilmoitetaan vastaavan lähinnä perinteistä kansansivistystyötä (Volksbildung). Jo se, että saksalainen komitea on luopunut määrittävän termin käytöstä, osoittaa että puheena oleva osa tehtäväkenttää on muita osaalueita vaikeammin käsitteellisesti jäsennettävissä ja rajattavissa (Englannin kielessä käytetään usein vastaavasti termiä non-vocational, esim. OECD 1977, 340-). Koko aineiston muissa luokituksissa on vastaavasta tehtäväalueesta käytetty $\mathrm{mm}$. termejä kulttuurilliset opinnot, vapaat yleissivistävät opinnot, vapaaaikaopinnot ja näiden määreiden erilaisia yhdistelmiä. Palaan tämän tehtäväluokan joihinkin erityiskysymyksiin vielä jäljempänä.

Kokoavana havaintona voi joka tapauksessa toistaa, että aikuiskasvatuksen tehtäviä määriteltäessä on eri maissa päädytty merkille pantavan usein pääasiallisesti samanlaisiin luokituksiin.

\section{Tehtäväalueiden jaotteluperusteet}

Mitkä ovat ne jäsentelyperusteet, joilla taulukossa esitettyihin ja vastaavantyyppisiin luokituksiin on päästy? Lähdeaineistossani ei luokitusten perusteita, kuten sanottu, ole yleensä paljonkaan analysoitu eikä edes esitelty. Aikuiskasvatusjärjestelmien kuvaukset toistavat suoraan vallitsevan käytännön: opintojen organisoimismuotojen tehtävänjaon ja ohjelmien eriytymisen. Myöskään suunnittelua palvelevissa selvityksissä ei tehtävien jäsentämisen käsitteelliseen pohdintaan ole juuri pyritty.

Eliasson ja Höglund määrittelevät tehtäväluokkansa aikuiskasvatuksen sosiaalisiksi funktioiksi, jotka koostuvat aikuisten erilaisten sosiaalisten roolien mukaisista opintotavoitteista (mt. s. 1:25). Aikuiskoulutuskomitean mukaan kysymys on käytännön koulutustehtävistä, jotka on ryhmitelty tehtäväalueiksi yhteiskunnan perustoimintojen ja niitä vastaavien toimintajärjestelmien mukaan (mt. s. 29). Saksan liittotasavallassa ovat sekä NordrheinWestfalenin valtionkomitea että RheinlandPfalzin aikuiskasvatuslaki ottaneet lähtökohdaksi ihmisen elämänalueet ja jaotelleet aikuiskasvatustehtävät niiden mukaan. Molemmat erottavat viisi tällaista kokemus- tai oppimisaluetta; ne ovat persoona, perhe, ammatti, vapaa-aika ja julkinen hallinto (Öffentlichkeit). Tehtäväalueet määräytyvät näiden mukaan (Hamacher 1974, 39).

Liveright ja Haygood määrittelevät jaottelunsa opinto-ohjelmien luokittamiseksi aikuisten oppimistarpeiden mukaan (mt. s. 9) selvittämättä millä perustein tarpeet on ryhmitelty. Heidän tehtäväluokkansa vastaavat kui- 
tenkin (ensimmäistä lukuun ottamatta) tiettyjä aikuisten elämäntodellisuuden keskeisiä toimintoalueita. Samalla tavoin on havaittavissa, että Titmus'in typologia noudattelee, tekijän sitä eksplikoimatta, tietynlaista elämänalueiden jäsentelyä. Vertailevan aikuiskasvatuksen tunnettu englantilainen edustaja on kartuttanut luokituksia seuraavanlaisella versiolla (Titmus 1976, 43-44):

1. Toinen koulunkäyntimahdollisuus

2. Rooliopinnot (lukuun ottamatta ammattiopintoja)

2.1. Persoonakohtaiset roolit (aviopuoliso, äiti/isä, eläkeläinen)

2.2. Sosiaaliset roolit (kansalainen, järjestön jäsen)

3. Ammattiopinnot

4. Persoonallisuutta kehittävät opinnot.

Kokoava päätelmäni on, että käsitellyissä luokitteluissa tehtäväalueiden erottelu pohjautuu niihin aikuisten elämäntoimintojen keskeisiin osa-alueisiin, lyhyesti elämänalueisiin, joiden mukaan heidän opintotavoitteensa eriytyvät ja niitä vastaavat opinto-ohjelmat koostuvat. Väitän että aikuiskasvatuskäytäntö on olennaisilta osin muotoutunut tämän jäsentävän periaatteen mukaan ja että sitä sen vuoksi noudattavat monet sellaisetkin luokitukset, joiden tekijät eivät ole jaotteluperusteitaan sen kummemmin analysoineet.

Elämänalueet heijastavat kunkin yhteiskunnan rakenteita, organisoitumismuotoja ja toimintajärjestelmiä. Sen vuoksi olennaisesti samanlaiseen tehtäväalueiden jakoon voidaan päätyä myös lähtemällä yhteiskunnan toiminnoista, kuten mm. Suomen ja Irlannin komiteain luokitukset osoittavat.

Koulukursseja vastaavat aikuisopinnot, toinen koulunkäyntimahdollisuus, on tehtäväalueena erikoisasemassa; se ei suuntaudu erityisesti millekään aikuiselämän osa-alueelle, vaan luo perustaa kaikille muille aikuisopinnoille ja yleensä jatkuvalle oppimiselle. Tätä erikoisasemaa ei muuta se, että aikuisten kouluopintojen keskeisenä tavoitteena on ammatillisten uramahdollisuuksien parantaminen.

Luokituksissa on siis tarkkaan ottaen käytetty toistakin jaotteluperustetta: opintojen suhdetta pohjakoulutukseen - Kuljutkinin luokittelusta tämä käy ilmikin. Vapaan sivistystyön piirissä on aikuiskoulutuskomitean tehtäväjaottelua kritikoitu ennen muuta siitä, että luokat eivät ole toisensa pois sulkevia, kun oppiaineita halutaan luokittaa tehtäväalueittain (esim. Tervonen 1980). Kritiikki perustuu useihinkin väärinkäsityksiin, joihin tässä puutun vain hyvin lyhyesti - perusteellisempaan selvittelyyn tulee ehkä tilaisuus muussa yhteydessä.

Ensinnäkin sentyyppinen jaottelu tehtäväalueisiin, jota aikuiskoulutuskomitean nelijakokin edus- taa, sisältää kyllä ajatuksen, että aikuiskasvatuksen opinto-ohjelmat tavoitteineen ja sisältöineen eriytyvät tehtäväalueittain. Tämä ei kuitenkaan merkitse, että oppiaineet voitaisiin suoraan, kaikkein vähiten pelkän tiedonalatunnuksen perusteella (psykologia, englannin kieli, musiikkioppi) sijoittaa tehtäväalueisiin. Onhan selvää, että samoja oppiaineita voidaan käyttää monella eri tehtäväalueella. Jotta luokitus voi tapahtua, on tiedettävä enemmän opinto-ohjelman tavoitteista ja sisällöistä (vrt. Harva 1970, 22-24 ja 1971, 76-). Toiseksi luokitus voidaan tehdä vain opintosuunnitelman varsinaisen tai ensisijaisen tavoitteen mukaan - yksittäiset opiskelijat saattavat käyttää esimerkiksi ammattiopintoja harrastustavoittein ja. harrastusopintoja ammatillisin tavoittein (ks. esim. Eliasson ja Höglund, mt. ja Titmus, mt.). Kolmanneksi tehtäväalueet eivät luokkina mene päällekkäin, kunhan huomataan että luokittelussa on yhdistetty - loogisesti aivan laillisella tavalla - useita kriteerimuuttujia ja että luokituskaavion on sen vuoksi oltava porrasteinen. Gestrelius antaa yhden porrastusmallin jakaessaan aikuiskasvatusen tavoitteet ensin pääluokkiin ammatilliset ja yleissivistävät opinnot ja edelleen jälkimmäisen alaluokkiin kelpoisuutta tuottavat ja kelpoisuutta tuottamattomat opinnot (Gestrelius 1968, 50, 68-69).

Kokonaan toinen asia on, että opinto-ohjelmien sijoittelussa tehtäväalueittain tulee vastaan monia muita pulmia kuten tehtäväalueiden välisiä rajausongelmia.

\section{Vapaa-aika ja tehtävä- alueet}

Kun tehtäväalueiden erottelussa lähdetään aikuisen elämänalueista, näyttää harrastusopintojen eli itseä toteuttavien opintojen elämänalueeksi määräytyvän vapaa-aika. Tällainen jäsentelytapa ei kuitenkaan ole ongelmaton, kaukana siitä. Vastassa on ensinnäkin vapaaajan käsitteen koko problematiikka. Eliasson ja Höglund noudattavat määritelmää, jonka mukaan kokonaisaika jakautuu itse asiassa vain työhön ja vapaa-aikaan; täten vapaaaikaan suuntautuvia opintoja (fritidsstudier) ovat kaikki muut kuin koulu- ja ammattiopinnot. Vapaa-ajan kriteeriksi voidaan toisaalta Dumazedierin tapaan asettaa itsensä toteuttamisen vapaus, jolloin sen ulkopuolelle jäävät perheeseen liittyviä tehtäviä myöten kaikki institutioituneet, sosiaalisen velvoitteen luontoiset toiminnot ("familial, social and political oblications"; Dumazedier 1975, 61). Näin määriteltyyn vapaa-aikaan puolestaan suuntautuvat nimenomaan ja vain itseä toteuttavat opinnot ja vastaavat tehtäväluokat. Verrattakoon Dumazedierin vapaa-ajan määritelmään 
esimerkiksi aikuiskoulutuskomitean harrastustavoitteisen koulutuksen luonnehdintaa. Komitean II mietinnön mukaan tähän tehtäväryhmään sijoittuvalle opiskelulle on ominaista se, että yhteiskunnan eri toimintajärjestelmät eivät ulkoa päin kiinteästi määrää oppimistavoitteita - kyseessä on elämisen laatuun itseisarvona kuuluva vapaa-ajan käyttötapa (mt. s. 29, 32-33).

Tältä pohjalta aikuiskasvatuksen tehtäväalueet voitaisiin ryhmitellä työelämään suuntautuviin, muihin tehtäviin suuntautuviin ja vapaa-aikaan suuntautuviin eli harrastusopintoihin. Lisäksi tulevat kaikkia elämänalueita palvelevat pohjakoulutuksen puutteita korvaavat opinnot. Juuri noiden 'muiden tehtävien" asettamien oppimistarpeiden selvittely olisi hyvin aiheellista niin suunnittelijoille ja tutkijoille kuin opintojen järjestäjille.

Tavoitteiden määräytyminen sosiaalisten instituutioiden ja niiden aikuisille asettamien tehtävien mukaan ei kuitenkaan erota tehtäväalueita jyrkästi vaan kyseessä on dimensio, jolla ulkoisen määräytymisen aste vaihtelee ääripäästä toiseen; voisi puhua vaikkapa kiinteätavoitteisuuden - vapaatavoitteisuuden tai tavoitteiden tehtäväsidonnaisuuden - omasääntöisyyden ulottuvuudesta. Tietty tehtäväsidonnaisuuden, tavoitteiden ulkoa määräytyvyyden kynnys on osoitettavissa ammattiopintojen ja yhteiskunnallisten opintojen välissä. Tällä perusteella olen joskus käyttänyt ryhmittelyä kiinteä- ja vapaatavoitteisiin opintoihin ja lukenut jälkimmäisiin yhteiskunnalliset ja harrastusopinnot (esim. Alanen 1974). Tarjosin tätä ryhmittelyä (ja termiä) aikuiskoulutuskomiteallekin mutta siitä luovuttiin rinnasteisen nelijaon hyväksi (I mietinnössä on ikäänkuin tunnusteltu useitakin erilaisia luokitusmalleja aina kahden muuttujan nelikenttää myöten; Kom.miet. 1971: A 29, 14-8, 44-55).

Palaan näihin ongelmiin erillisessä harrastusopintoja käsittelevässä kirjoituksessa.

Meidän yhteiskunnallemme on ominaista työn ja vapaa-ajan vastakkaisuus. Tämän vuoksi vapaa-aikaan suuntautuvat opinnotkin mielletään helposti joko työlle alisteisiksi (elpyminen, kompensoiminen, uusiintuminen) taikka sitten toiminnaksi, jonka merkitys rajoittuu vapaa-aikaan jonakin erillistyneenä elämänlohkona. Yleensäkin yhteiskunnan toimintojen ja aikuisen elämänalueiden segmentoituminen pyrkii heijastumaan myös aikuisopintojen eriytymiseen. Persoonallisuuden kaikinpuolinen kehittyminen jää aikuiskasvatuksen kokonaistavoitteena fraasiksi ellei yri- tetä selvittää, mitä tämän tavoitteen toteuttaminen didaktisesti vaatii eritoten niissä aikuisopinnoissa, jotka pakostakin sisällöllisesi rajoittuvat suppeisiin opinto-ohjelmiin kerrallaan.

\section{Lähteet:}

Adult Education in Ireland. 1973. A Report of a Committee appointed by the Minister for Education. The stationery Office. Dublin.

Alanen, A. 1974. Aikuiskoulutuksen muuttuva kokonaiskuva. Aikuisopiskelijan opinto-opas. Iltaopiskelijain Liitto r.y. Hämeenlinna.

Dumazedier, J. 1975. The conception of changes in leisure and education. Society and Leisure 3, 1975.

Eliasson, T. \& Höglund, B. 1971. Vuxenutbildning i Sverige. En strukturell översikt. Utbildningsdepartementet. Stockholm.

Gestrelius, K. 1968. Systematisk vuxenutbildning. Läromedelsförlagen. Lund.

Hamacher, P. 1974 Entwicklungsplanung für Weiterbildnung. Westermann. Braunschweig.

Harva, U. 1971. Aikuisten opettaminen. Tammi. Helsinki.

Harva, U. 1970. Aikuiskasvatuksen tavoitteiden asettaminen. Karjalainen, E. (toim.) Vapaan sivistystyön tavoitteet. Weilin + Göös. Tapiola.

Komiteanmietintö 1971: A 29. Aikuiskoulutuskomitean I osamietintö.

Komiteamietintö 1975: 28. Aikuiskoulutuskomitean II osamietintö.

KuIjutkin, J.N. 1974. Aikuiskasvatus Neuvostoliitossa. APN: Neuvostoliitto tänään 12, 1974.

Liveright, A.A. \& Haygood, N. (eds.) 1969. The Exeter Papers. Boston.

Lowe, J. 1975. The Education of Adults. A World Perspective. The Unesco Press. Paris.

OECD. 1976. Comprehensive Policies for Adult Education. Paris.

OECD. 1977. Learning opportunities for adults. Vol. IV. Participation in Adult Education. Paris.

Parkyn, G.W. 1973. Towards a conceptual model of life-long education. Educational Studies and Documents 12. Unesco. Paris.

Tervonen, I. 1980. Harrastustavoitteisuuden ongelmasta. Opistolehti 4. 1980.

Titmus, C. 1976. Proposed theoretical model for the comparative study of national adult education systems in Europe. Society and Leisure, Vol. 8, No 2 .

Strukturplan für das Bildungswesen. 1970. Bildungskomission des Deutschen Bildungsrates. Stuttgart.

Unesco. 1972. A Retrospective International Survey of Adult Education. Unesco/Confedad 4. Paris.

Vapaan kansansivistystyön suhde koululaitokseen. 1967. Vapaa sivistystyö koulutusyhteiskunnassa. Vapaan kansansivistystyön XV vuosikirja. Otava. Mikkeli. 